\title{
Isolation and Characterization of some Bacteriophages and
}

\section{their Associated Bacteria in Sea Food: Phage-Host Interaction}

\author{
Sahar W M Hassan*
}

\begin{abstract}
Background: Economic loss due to diseases is a major problem in aquaculture. A number of bacterial illnesses may arise from the consumption of sea food that has been contaminated at source or during the processing. This study aims to isolate and characterize some bacteriophages specific for the most common sea food pathogens in addition to their associated bacteria. The work also extended to study the host-phage interaction and the potential use of phages as antibacterial agents to control sea food infecting pathogens. Materials and methods: Estimation of Vibrio spp and Aeromonas spp. in addition to their associated phages in different sources of sea food such as fish (Tilapia sp.), clam (Tapes decussatns) and crab (Callinectes sapidus) was carried out. Results: Crab exhibited the highest counts (200 CFU/g) of Vibrio spp., while the highest counts of Vibriophages (1500 PFU/g) were detected in clam. Fish harbored the highest counts $(30 \mathrm{CFU} / \mathrm{g})$ and $(3000 \mathrm{PFU} / \mathrm{g})$ of Aeromonas spp. and Aeromonas phages, respectively. Three different phages (VPS1, APS2 and APS3) in addition to the isolated bacteria were characterized. Results showed that VPS1, APS2 and APS3 were different, which was confirmed by molecular characterization using RAPD-PCR and the protein profile. APS 3 was entrapped into calcium alginate beads and tested as antibacterial agent against Aeromonas hydrophila. Efficiency of APS3 was superior to the free particles $(p<0.05)$ and realized 2.7 fold decrease in bacterial growth rate. Phage seeded beads were recycled for 7 successive cycles. Their activity was reduced up on reuse. Recommendations: This study revealed that phages remain an excellent potential tool for control of bacterial pathogens. Further research and manipulation of the isolated phages could produce novel effective biocontrol agents of sea food infectious diseases in marine aquaculture systems
\end{abstract}

Key words: Bacteriophages; characterization; entrapment; phage-host interaction; antibacterial activity.

\section{INTRODUCTION}

Sea food is a popular part of the diet in many parts of the world and in some countries constitutes the main supply of animal protein. Great economic losses in aquaculture are attributed to infection by different pathogens where microbial sea food-borne diseases represents 10 to $20 \%$ of the total food-borne outbreaks; most of them are from bacterial infections. ${ }^{(1,2)}$ The microbiological flora in the sea food

\footnotetext{
*Lecturer of microbiology, Marine environment division, National Institute of Oceanography and Fisheries, Alexandria
} 
is believed to be a reflection of general contamination in the aquatic environment where accumulation and concentration of bacteria and viruses from the environment is generally taking place. ${ }^{(3)}$ Different pathogenic bacteria were previously isolated from sea food. ${ }^{(4)}$ Vibrio spp. are an important cause of illnesses in molluscan bivalves that concentrate different particles during their filter feeding. ${ }^{(5)}$ For a long time vibriosis caused by Vibrio anguillarum was the most serious disease in cultured populations. It causes a bacteraemia in salmonoid fish that leads to internal haemorrhage which leads to loss of yield and quality of fish after infection. ${ }^{(6)}$ Aeromonas hydrophila, the most common bacterial pathogen in fresh water fish, has been recognized to be the etiological agent of many pathological conditions, including tail rot, Aeromonas septicemia and epizootic ulcerative syndrome. ${ }^{(7)}$

Control of diseases in aquaculture was dependant on the use of chemical compounds, which resulted in the development of antibiotic resistance and its transfer among cells through plasmids or bacteriophages. Therefore there is an urgent need to have alternative tools for pathogen control in aquaculture. ${ }^{(8)}$

Bacteriophages are bacterial viruses extremely abundant in nature and believed to be important in controlling bacterial populations in natural systems. ${ }^{(9)}$ Phage therapy may represent a viable alternative to antibiotics to inactivate pathogenic bacteria. $^{(10)}$ To find the ecological impact of marine phages on bacterial populations, it is necessary to carryout a detailed study of their diversity and host specificity. Also, virus-host interaction provides model systems to determine the effect and activity of the phage infection on the structure of the natural bacterial communities.

Although bacteriophages were proposed for several applications in food safety to control the major pathogenic bacteria, ${ }^{(11)}$ only few applications in 
seafood were reported. ${ }^{(12)}$ The treatment of microbial diseases is still difficult and might involve environmental hazards. A possible method to confront this problem might be the oral administration of antimicrobial materials to the larvae through the food chain, using the immobilization technique, ${ }^{(13)}$ in which the active components are covered by a layer of another material such as alginate, carrageenan and agarose. ${ }^{(14)}$

Immobilization, either by covalent linkage to an insoluble matrix or by entrapment into gel of film support, could provide stability to phages as reported for enzymes and bacteriocins. ${ }^{(15)}$ Immobilized phage could be particularly useful to create antimicrobial surfaces against pathogenic bacteria and was used in different applications. ${ }^{(16-19)}$

The aim of the present study was to estimate the counts of different groups of pathogenic bacteria such as Vibrio spp. and Aeromonas spp., in addition to their specific phages in different sources of sea food. The work also extended to include isolation and characterization of some bacteriophages and their associated bacteria. Host-phage interaction was carried out to study the potential use of phages as ecofriendly alternatives to the chemotherapeutic agents.

\section{MATERIALS AND METHODS}

Cross section and experimental designs were followed. Fresh samples of fish (Tilapia sp.), clam (Tapes decussatns) and crab (Callinectes sapidus) were purchased from the market in January, 2010. Samples were held at 5 to $10^{\circ} \mathrm{C}$ during shipment for 24 to 30 hours prior to analysis. Ten of each sample type were scrubbed, shucked, mixed with an equal (1:1) weight of Butterfield's phosphate-buffered saline and blended. $^{(20)}$

The prepared samples were diluted in sterile sea water and $0.1 \mathrm{ml}$ of the suitable dilution was plated on Aeromonas medium base (Ryan) (CM833) with ampicillin 
selective supplement (SRO136) for the procedures described in the instruction enumeration of Aeromonas spp., while manual.

Vibrio spp. was detected using Phages were isolated directly from the Thiosulphate Citrate Bile Salt (TCBS) agar. supernatant of fish kidney, clam and crab Plates were incubated at $30^{\circ} \mathrm{C}$ for 24 hours homogenates as previously described. ${ }^{(21)}$ and then 10 different colonies were All media and diluents were prepared in selected and sub cultured onto nutrient seawater and diluted with deionized agar for 24 hours.

A total of ten bacterial isolates were chosen arbitrarily. Colony morphology characters were examined on nutrient agar plates after 24 hours incubation. Gram stain reaction was also performed. Temperature range $\left(10-40^{\circ} \mathrm{C}\right)$, sodium chloride requirement (6-10\%), antibacterial activity against some pathogens including Staphylococcus aureus ATCC 6538, Pseudomonas aeruginosa ATCC $8739, P$. fluorescens, V. anguillarum, Aeromonas hydrophila, and Escherichia coli were performed. Other physiological characters were also studied. One strain of each phenon was selected and identified using API 20A Kit (Biomereiux Comp.) following seawater. Casamino acids peptone marine (CPM) broth $(5.0 \mathrm{~g}$ of Casamino Acids [Difco], $5.0 \mathrm{~g}$ of Bacto Peptone [Difco], and 1.0 liter of seawater, autoclaved for $15 \mathrm{~min}$ at $121^{\circ} \mathrm{C}$ ) was used as a growth medium. Serial dilutions of each supernatant were prepared in sterile seawater. Aliquots of each dilution were adsorbed to $0.2 \mathrm{ml}$ of log-phase host cultures for $15 \mathrm{~min}$, and virulent phages were detected by using the soft-agar overlay technique. ${ }^{(22)}$ The plating medium and soft-agar overlay were prepared with CPM medium supplemented with 1.5 and $0.7 \%$ Bacto Agar (Difco), respectively. The plates were incubated at $30^{\circ} \mathrm{C}$, and plaques were detected at 24 48 hours. The plaque types, different in 
shape and size were isolated, purified and propagated to represent different phage isolates, namely VPS1, APS2 and APS3. The titre of each isolate was determined.

Recovery of purified intact phage was achieved according to Sambrook et al. ${ }^{(23)}$ To each phage lysate tube, RNase A and DNase I (Sigma Chemical Co.) were added to a final concentration of $1 \mu \mathrm{g} / \mathrm{ml}$ and incubated at $37^{\circ} \mathrm{C}$ for $30 \mathrm{~min}$. Polyethelene glycol (PEG, molecular biology grade, $\mathrm{MW}=8,000)$ and sodium chloride were added to the tubes, each at $9.3 \mathrm{~g}$ and $5.8 \mathrm{~g}$ per $100 \mathrm{ml}$ of lysate, respectively. The tubes were inverted several times to dissolve PEG and sodium chloride completely. The tubes were kept on ice for two hours and the precipitate was then recovered by centrifugation at $10,000 \mathrm{rpm}$ for $20 \mathrm{~min}$ at $4^{\circ} \mathrm{C}$. The supernatant was allowed to drain, and the precipitate containing the purified intact phage isolates was each resuspended by gentle vortexing in $2 \mathrm{ml}$ of phage buffer.

The morphology of the three phage isolates VPS1, APS2 and APS3 were investigated with electron microscopy. Phages were negatively stained with $2 \%$ sodium tungestate in bi-distilled water at $\mathrm{pH}$ 6-7.5. Five $\mu \mathrm{l}$ of each phage suspension were dropped onto a carboncoated grid. The excess liquid was removed with filter paper after $1 \mathrm{~min}$. Five $\mu \mathrm{l}$ of dye solution were added and after 1 min, the grid was dried. The grids were then examined and electron micrographs were taken with a T. E. M. (JEOL $100 \mathrm{CX}$ ) operating at $80 \mathrm{kv}$.

Phage DNA was isolated and purified as follows: each supernatant containing the purified phage was transferred to another tube and $100 \mu$ l of $10 \%$ sodium dodecyl sulphate (SDS) and $100 \mu$ of $0.5 \mathrm{M}$ EDTA pH 8.0 per $100 \mathrm{ml}$ of phage lysate were added. The tubes were incubated at $68^{\circ} \mathrm{C}$ for $20 \mathrm{~min}$, after which phenol/chloroform extraction was carried out at $12,000 \mathrm{rpm}$ for $5 \mathrm{~min}$ at $4^{\circ} \mathrm{C}$. The upper aqueous phase was then transferred to a clean tube, an equal volume of isopropanol was added and the tubes were kept at $-20^{\circ} \mathrm{C}$ 
for 1 hour, after which the DNA was collected by centrifugation at $12,000 \mathrm{rpm}$ for $20 \mathrm{~min}$ at $4^{\circ} \mathrm{C}$. Each supernatant was drained carefully and the pellets were washed with $1 \mathrm{ml}$ of $70 \%$ ethanol, dried at room temperature for $15 \mathrm{~min}$ and finally resuspended in $200 \mu \mathrm{l}$ of sterile distilled water. ${ }^{(23)}$

The purified phage DNA isolated from each phage isolate was analyzed using Random Amplification of Polymorphic DNAPolymerase Chain Reaction (RAPD-PCR)

Amplification reactions were performed in a total volume of $50 \mu$ containing 100 $\mu \mathrm{M}$ each of dATP, dTTP, dCTP, and dGTP, $0.2 \mathrm{M}$ of each RAPD primer, $25 \mathrm{ng}$ of template DNA and 1.25 units of Taq polymerase in $1 \mathrm{x}$ PCR buffer containing $2.5 \mathrm{mM} \mathrm{MgCl}_{2}$. The reaction mixtures were subjected to amplification as follows: 45 cycles of $1 \mathrm{~min}$ at $94^{\circ} \mathrm{C}, 1 \mathrm{~min}$ at $37^{\circ} \mathrm{C}$ and $1 \mathrm{~min}$ at $72^{\circ} \mathrm{C}$. After the last cycle, samples were maintained at $72^{\circ} \mathrm{C}$ for $10 \mathrm{~min}$. Amplification products were analyzed by agarose gel (1\%) electrophoresis, stained with ethidium bromide and DNA profiles were documented and analyzed using Alfa Imager 1200 Tm. Faint, $<1 \%$ of total intensity, and inconsistent bands most likely the result of poor primer-template matching, were excluded from the analysis. Amplification reactions were done using one of the following primers: primer 1:6-d: 5`-(AAGAGCCCGT)-3`; primer 2: 6-d :5`(AACGCGCAAC)-3` and primer 3: 6-d: 5 (CCCGTCAGCA)-3`.

The proteins were analyzed by sodium dodecyl sulfate-polyacrylamide gel electrophoresis (SDS-PAGE) according to Laemmli, ${ }^{(24)}$ using SDS-PAGE (10\%). Protein samples were prepared by mixing $50 \mu \mathrm{g}$ proteins with $5 \mathrm{X}$ sample application buffer [0.6 M Tris- $\mathrm{HCl}, \mathrm{pH} 6.8,1 \%(\mathrm{w} / \mathrm{v})$ SDS, $10 \% \quad \beta$-mercaptoethanol, $10 \%$ sucrose and $0.05 \%$ bromophenol blue] to give a final concentration 1X. Samples (50 ug each) were then boiled in water bath for 3 minutes at $95^{\circ} \mathrm{C}$. Samples were applied to the slab gel along with a molecular 
weight marker. Electrophoresis was carried out at a constant voltage 150 volts for about 2 hours. The gel was then stained with Coomassie Brilliant Blue R-250 [0.1\% Coomassie Brilliant Blue R-250 in $50 \%$ Methanol, $10 \%$ acetic acid] for 2 hours with gentle agitation at room temperature. The gel was destained overnight using a destain solution $(100 \mathrm{ml}$ methanol, $70 \mathrm{ml}$ acetic acid and $830 \mathrm{ml}$ distilled water).

The isolated bacteria, in addition to three reference strains of $V$. anguillarum, A. hydrophila and P. fluorescens, were grown to log phase and plated on CPM medium by the soft-agar overlay technique. After 1 hour, $4 \mu$ from a phage stock was spotted onto the plates, and the plates were incubated overnight at $30^{\circ} \mathrm{C}$. Bacterial strains were considered susceptible to phages that produced either clear or turbid plaques.

APS3 particles were entrapped using sodium alginate $(2 \% \mathrm{w} / \mathrm{v})$. Sodium alginate was purchased from Sisco Research
Laboratories Pvt. Ltd., India. Beads were obtained by mixing the active phage with sodium alginate solution, then homogenized and dropped from a hydrodermic syringe to $100 \mathrm{ml}$ of calcium chloride solution (2\%) with constant stirring at room temperature. The formed beads were maintained in the gelling bath to harden for 1 hour. Then, they were filtered through a Whatman No. 1 paper and washed with sterile distilled water.

To test the antibacterial activity of the free and entrapped phage, the test bacteria were grown at $30^{\circ} \mathrm{C}$ for 24 hours on nutrient broth. A cell suspension of each microorganism was used for the antimicrobial test. The antibacterial activity was evaluated by using the shake-flask method. ${ }^{(25)}$ In this test, $50 \mathrm{ml}$ of each cell suspension and predetermined amounts of beads were placed in a sterilized flask and continuously shaken at $150 \mathrm{rpm}$ on a rotary shaker. At prescribed time intervals, $1.0 \mathrm{ml}$ of sample solution from the bead/microbial 
suspension system was removed by used as a limit to indicate statistical pipetting and optical density (O.D.) was significance.

measured at $550 \mathrm{~nm} .^{(26)}$ The optical density

\section{RESULTS}

of the free phage samples was also

Different samples of sea food included measured as mentioned above. The active fish, crab and clam were purchased from the entrapped phage particles were recycled market. Estimation of the most common for seven successive cycles.

bacterial pathogens (Vibrio spp. and

\section{Statistical analysis}

Aeromonas spp.) was carried out in addition to

Results were analyzed by numerical counts of the associated phages. As shown in techniques using the simple matching coefficient $(\mathrm{SsM})^{(27)}$ and clustering was figure 1, Crab exhibited more Vibrio spp (200 CFU/g) than clam (100 CFU/g) and fish (50 achieved by unweighted pair group CFU/g). Only $4 \mathrm{CFU} / \mathrm{g}$ of Aeromonas spp was average linkage (UPGMA). ${ }^{(28,29)}$ The recorded for clam while fish exhibited the computations were performed by using SYSTAT-PC program V7. ${ }^{(30)}$

highest counts (30 CFU/g) of Aeromonas spp. On the other hand, clam harbored the highest

Data analysis was performed with the software package Microsoft Excel, Version 2003. Statistically significant difference was determined using t-test and $p<0.05$ was counts of vibriophages (15000 PFU/g) followed by fish (5000 PFU/ g), while only fish exhibited high counts of Aeromonas phages (3000 PFU/g). 


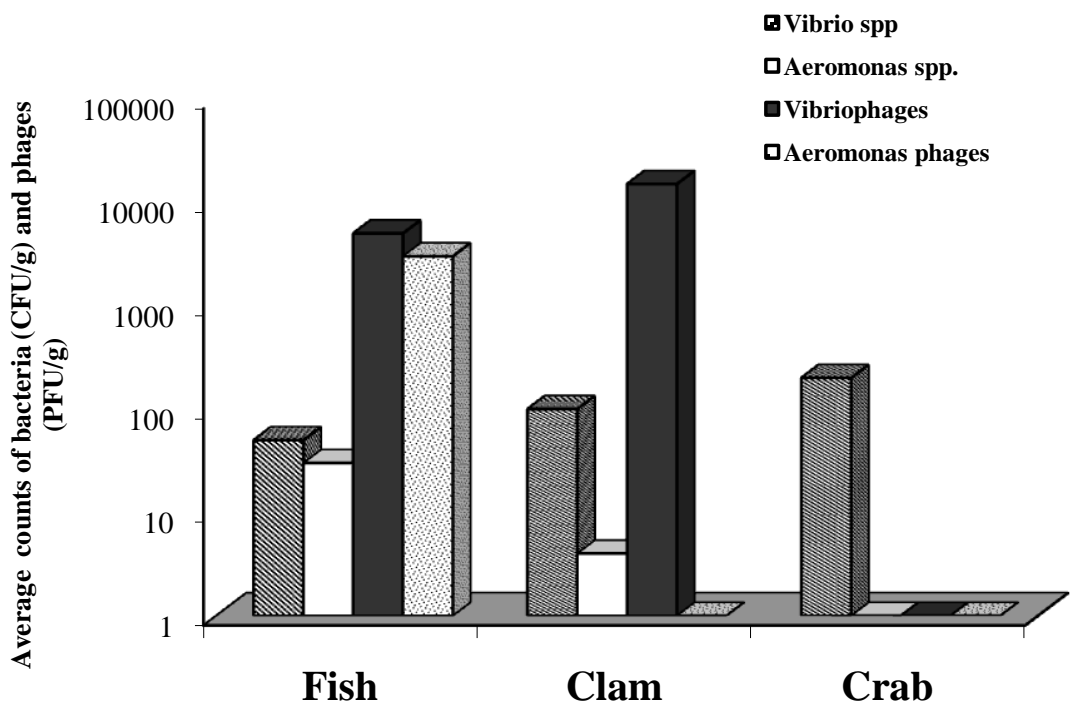

Figure 1. Average total counts of Vibrio spp. and Aeromoas spp. (CFU/g) and their corresponding phages (PFU/g) in different sea food samples (Fish, clam and crab)

Ten different bacterial isolates were chosen and coded as S1-S10. They were differentiated according to morphological and physiological characteristics as shown in table 1. All isolates were numerically clustered into three phena (A, B and C) at similarity level $79.29 \%$ as shown in the dendogram in figure 2 .

Phenon A: contained 4 isolates with $81 \%$ similarity. Three of them were isolated from crab and only one from clam.

Phenon B: This phenon harbored 4 strains with $82 \%$ similarity. Two strains were isolated from crab and the other two were from clam.

Phenon C: This phenon was the minor group (2 strains) with $84.2 \%$ similarity. They were isolated from clam and fish.

One strain of each phenon was selected and identified by the aid of Bergy's Manual of Systematic Bacteriology. Member of phenon A was identified as V. parahaemolyticus and member of phenon $\mathrm{B}$ was identified as $V$. alginolyticus while member of phenon $\mathrm{C}$ was identified as Aeromonas hydrophila . 
Table 1. Main characteristics of the isolated bacterial isolates

\begin{tabular}{|c|c|c|c|}
\hline Characters & $\begin{array}{c}\text { Phenon A } \\
4 \text { strains }\end{array}$ & $\begin{array}{c}\text { Phenon B } \\
4 \text { strains }\end{array}$ & $\begin{array}{c}\text { Phenon C } \\
2 \text { strains }\end{array}$ \\
\hline \multicolumn{4}{|l|}{ 1. Colour } \\
\hline Yellow & 25 & 0 & 0 \\
\hline Green & 75 & 100 & 100 \\
\hline \multicolumn{4}{|l|}{ 2. Cell shape } \\
\hline Rod & 100 & 100 & 100 \\
\hline Cocci & 0 & & \\
\hline 3- Diffusible pigments & 0 & 0 & 0 \\
\hline \multicolumn{4}{|l|}{$\begin{array}{l}\text { Physiological characters } \\
1-\text { Growth at different salt concentration } \\
(\% \circ)\end{array}$} \\
\hline 6 & 100 & 100 & 50 \\
\hline 8 & 75 & 75 & 100 \\
\hline 10 & 50 & 75 & 50 \\
\hline \multicolumn{4}{|l|}{ 2- Growth at different temperatures $\left({ }^{\circ} \mathrm{C}\right)$} \\
\hline 10 & 0 & 0 & 0 \\
\hline 20 & 0 & 0 & 0 \\
\hline 30 & 100 & 100 & 100 \\
\hline 40 & 100 & 100 & 100 \\
\hline \multicolumn{4}{|l|}{ Physiological characters } \\
\hline \multicolumn{4}{|l|}{ Production of } \\
\hline Catalase & 25 & 25 & 0 \\
\hline Urease & 75 & 75 & 100 \\
\hline Indole & 0 & 0 & 100 \\
\hline Gelatinase & 75 & 75 & 100 \\
\hline Nitrate reduction & 0 & 0 & 100 \\
\hline \multicolumn{4}{|l|}{ Utilization of } \\
\hline Glucose & 100 & 75 & 100 \\
\hline Fructose & 100 & 100 & 100 \\
\hline Sucrose & 25 & 25 & 100 \\
\hline \multicolumn{4}{|l|}{ Degradation of } \\
\hline Agar & 0 & 0 & 0 \\
\hline Starch & 100 & 100 & 100 \\
\hline Casein & 0 & 100 & 50 \\
\hline \multicolumn{4}{|l|}{ Antibiosis against } \\
\hline$P$. aeruginosa & 0 & 100 & 0 \\
\hline S.aureus & 75 & 50 & 50 \\
\hline A. hydrophila & 50 & 50 & 50 \\
\hline V.anguillarum & 0 & 0 & 0 \\
\hline P.fluorescens & 50 & 100 & 0 \\
\hline E.coli & 50 & 75 & 0 \\
\hline Number of identified strain & 1 & 1 & 1 \\
\hline \multirow[t]{2}{*}{ The probable identification } & V. & V. & A. \\
\hline & parahaemolyticus & alginolyticus & hydrophila. \\
\hline
\end{tabular}




\section{Dendrogram with single Linkage and Euclidean Distance}

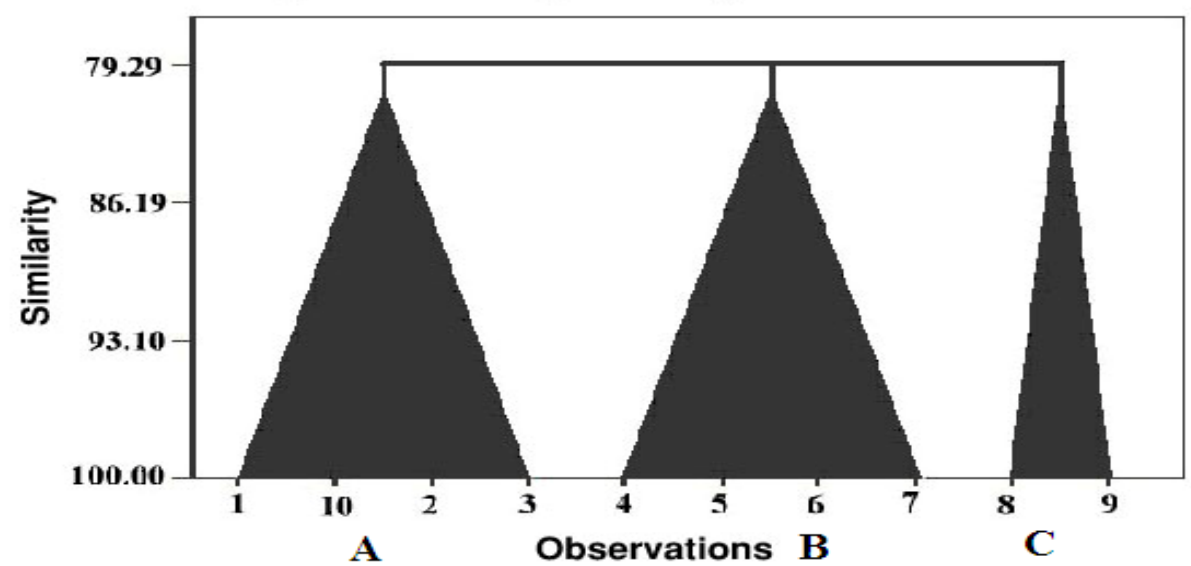

NB. The numbers (1-10) refer to (S1-S10).

Figure 2. Simplified dendogram showing the similarity levels among the isolated bacteria based on the SsM-UPGMA analysis

\section{Characterization of the isolated phages}

1- Electron microscopy examination and identification of the phage isolates

The study was extended to isolation of different phages depending on morphology and size as shown in figure 3.

Electron micrographs showed that VPS1 (figure 3a) has icosahedral head and long tail and thus belongs to family
Siphoviridae morphotype 1 as it has collar like structure between the head and the tail with no additional appendages on its head or tail. On the other hand, APS2 (figure 3b) belongs to family Myoviridae morphotype 2 as it has icosahedral head and long tail with no special appendages. APS3 (figure 3c) has icosaherdal head and short tail and thus belongs to family Podoviridae. 


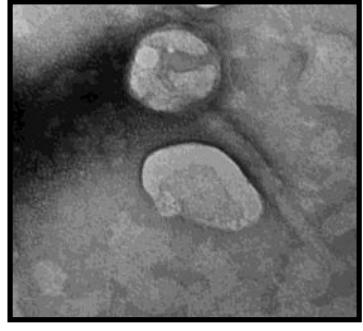

$\mathbf{a}$

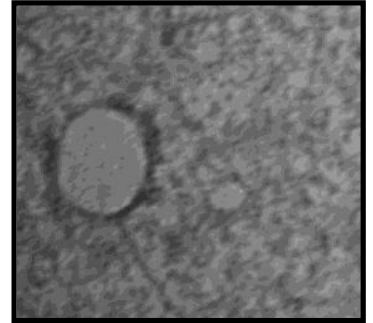

b

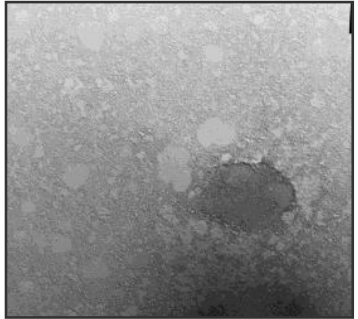

c

Figure 3. Electron micrographs showing a) VPS1, b) APS2 and c) APS3

2- Molecular characterization of the 1188 bp for APS2, which was absent isolated phages completely in case of VPS1 and APS3.

RAPD-PCR analysis was used as a tool to differentiate between the three phages based RAPD results with primer 3 were also able to differentiate between the three phages. on detecting the polymorphic regions. This There were bands of molecular sizes 185 technique was performed using 3 arbitrary and $130 \mathrm{pb}$ for APS2 and bands of primers. Primer 1: 6-d: 5'-(AAGAGCCCGT)molecular sizes 165 and $115 \mathrm{pb}$ for APS3, 3'; primer 2: 6-D: 5'(AACGCGCAAC)-3 and which were completely absent from VPS1. primer 3: 6-d: 5'(CCCGTCAGCA)-3'. Figure 4 There were relatively identical pattern of shows that all the used primers were able to bands mobility in case of VPS1 and APS3, differentiate between the three phages. however they were different from the RAPD-PCR results obtained using primer 2 mobility pattern of bands obtained from showed a specific band of molecular size APS2 using primer 1. 


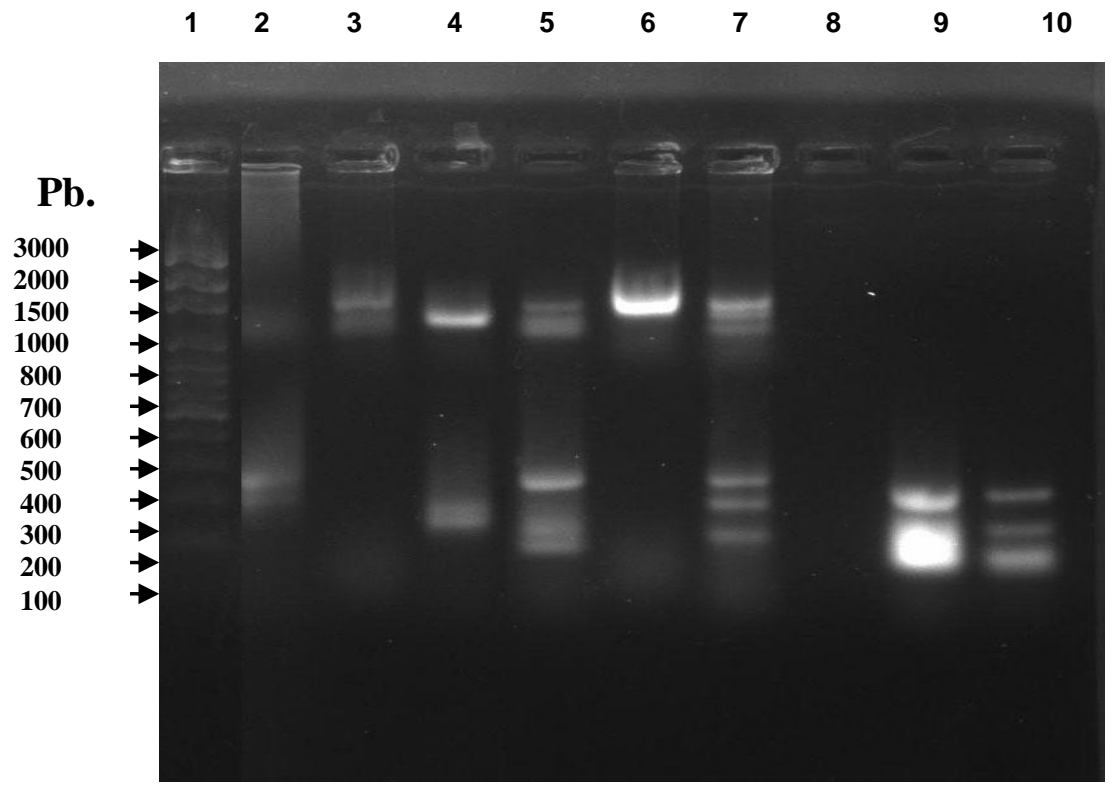

Figure 4. Agarose gel (1\%) electrophoresis of RAPD products from VPS1, APS2 and APS3 phages template DNA with arbitrary primers; primer 2 lanes (2-4); primer 1 lanes (5-7); and primer 3 lanes (8-10). Lane 1 represents lambda/HindIII- X174/HaellI marker

Protein profiles of the isolated phages using (SDS- PAGE) analysis

SDS PAGE analysis of purified VPS1, APS2 and APS3 (figure 5) showed different patterns. While VPS1 exhibited bands with molecular weight in the range of 17-175
$\mathrm{KDa}$, APS2 had bands in the range of 17 $80 \mathrm{KDa}$, and the range was $17-46 \mathrm{KDa}$ in case of APS3. It was noticed that there were common shared bands among the three phages which were nearly in the range of $30-46 \mathrm{KDa}$. 


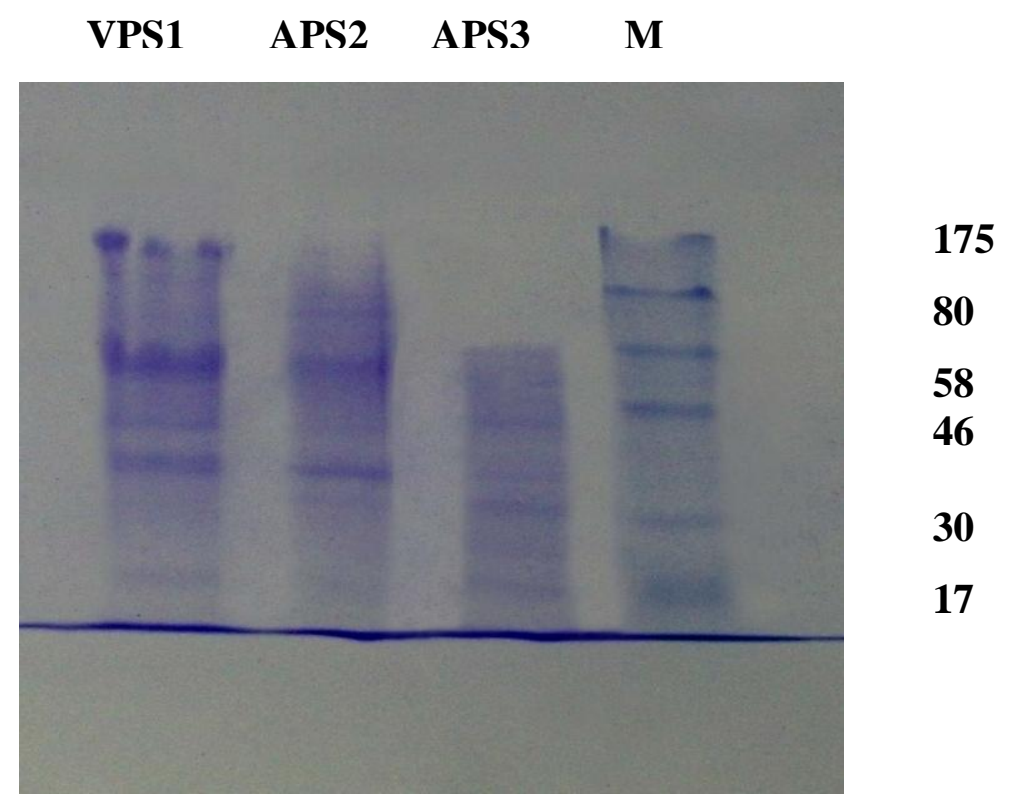

Figure 5. SDS-Polyacrylamide gel (10\%). Lanes 1, 2 and 3 represent $50 \mu \mathrm{g}$ of the precipitated proteins of VPS1, APS2 and APS3 while lane M represents molecular weight protein marker

\section{3- The host range of the isolated phages}

The isolated phages were tested for their host specificity to 10 of the isolated species in addition to 3 reference strains including Vibrio anguillarum, Pseudomonas fluorescens and Aeromonas hydrophila. As shown in table 2, VPS1 and APS2 showed narrow range of host specificity where, VPS1 infected only S7,
S10 and $V$. anguillarum causing clear plaques. APS2 was able to infect only3 species including, S7, S10 and A. hydrophila. On the other hand, APS3 exhibited wide host range realizing infectivity to all the tested species except for $V$. anguillarum and $P$. fluorescens and thus was chosen to complete the study. 
Table 2. Host range of the isolated phages

\begin{tabular}{lccc}
\hline & \multicolumn{3}{c}{ The isolated bacteriophages } \\
\cline { 2 - 4 } Host bacteria & VPS1 & APS2 & APS3 \\
\hline A. hydrophila & - & + & + \\
V. anguillarum & + & - & - \\
P. fluorescens & - & - & - \\
S1 & - & - & + \\
S2 & - & - & + \\
S3 & - & - & + \\
S4 & - & - & + \\
S5 & - & - & + \\
S6 & - & - & + \\
S7 & + & + & + \\
S8 & - & - & + \\
S9 & - & - & + \\
S10 & + & + & + \\
\hline
\end{tabular}

Phage-host Interaction: Antibacterial activity of APS3 against A. hydrophila

The aim of this part was to study the effect of phage on the surrounding bacterial population. APS3 was chosen as a model to study the interaction with its host bacteria ( $A$. hydrophila) and the study extended to evaluate the effect of immobilization on this interaction and the possibility to use the active phage as biocontrol agent against the pathogenic bacteria.
Entrapment of APS3 into calcium alginate beads was performed to study the interaction with its bacterial host. As shown in figure 6 , the entrapped phage particles were superior in its effect in reducing the growth rate of $A$. hydrophila than the free phage (significant at $p<0.05$ ). The antibacterial activity started 4 hours after the addition of the calcium alginate loaded phage particles realizing about 2.7 fold decrease in the growth rate of $A$. hydrophila and extended until the end of the experiment. 


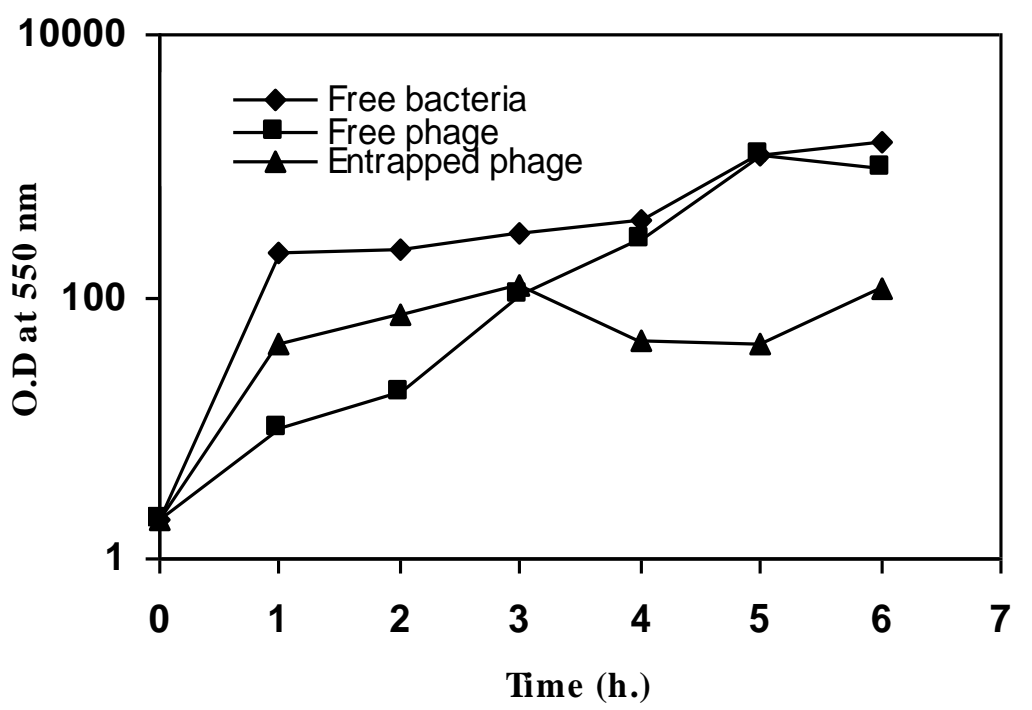

Figure 6. Effect of entrapment of APS3 on the interaction between it and A. hydrophila

Recycling of the entrapped phage particles phage particles in its action against the APS3 seeded alginate beads were tested host bacteria only at the first cycle and was for their efficiency in reducing the growth rate reduced in the next cycles. However, it was of $A$. hydrophila for seven successive cycles. still active against the pathogenic bacteria figure 7 showed that the entrapped phage compared to the growth rate of free particles were better than free bacteria. 


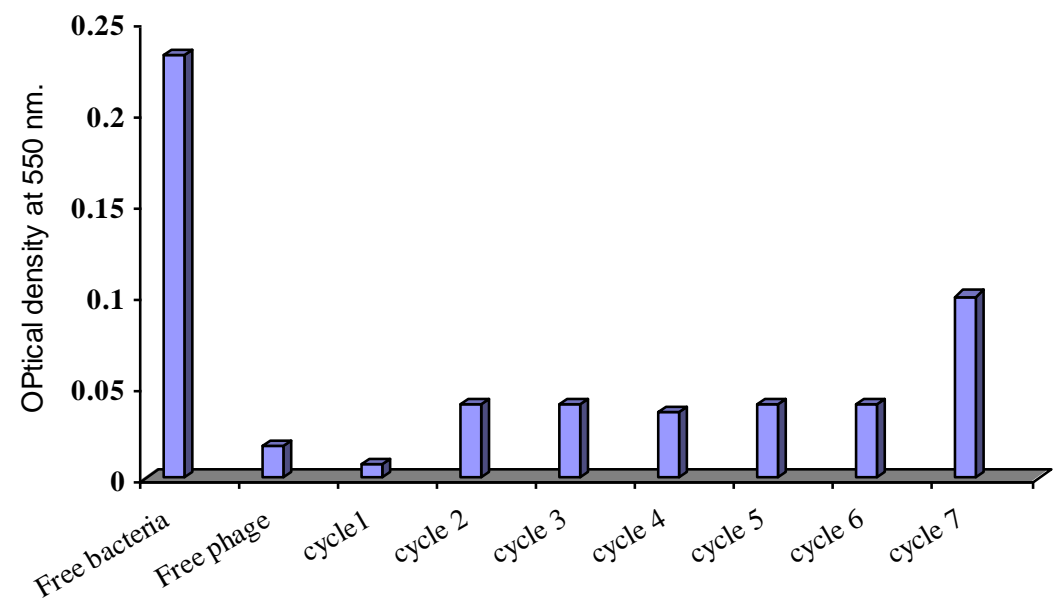

Figure 7. Effect of recycled APS3 seeded alginate beads on the growth rate of $A$. hydrophila

\section{DISCUSSION}

The presence and distribution of $a l^{(4)}$ This may be attributed to high pathogenic bacteria such as Vibrio and tolerance of Vibrio spp. and their phages to Aeromonas spp. provide important a wide range of salinity and their tend to be information for control of water quality. ${ }^{(31)}$ In more common in warm water, when the present study, Vibrio spp. and their temperature exceeds $17^{\circ} \mathrm{C} .^{(32)}$ Their associated phages detected in the tested concentration in the aquatic environment sea food samples outnumbered the counts and in foods of marine origin is a function of Aeromonas spp. and their associated of the geographic and hydrographic phages. Also, there was complete absence conditions in the area, and varies of Aeromonas spp. in crab which was according to the time of year and location consistent with that reported by Boutaib et within the lagoon systems. ${ }^{(33)}$ 
In the present study, ten of the isolated bacterial spp. were chosen and characterized. The general characteristics of temperature and $\mathrm{Na} \mathrm{Cl}$ requirements were indicative of their marine origin as was described by Wichels et al. ${ }^{(34)}$ The identified strains were previously isolated from sea food samples. ${ }^{(35)}$ These included V. parahaemolyticus, V. alginolyticus, and A. hydrophila and also were documented as hosts for phages. ${ }^{(21)}$

Electron microscopy was used to classify the isolates into their appropriate taxonomic position. ${ }^{(36)}$ In the present study, VPS1 and APS2 assigned to order caudovirales as they have long tail and double stranded DNA. Our results were in accordance with that reported by Fattouh et al., ${ }^{(16)}$ and Pereira et al., ${ }^{(10)}$ where the tailed phages predominated other morphotypes. VPS1, APS2 and APS3 were found to belong to family Siphoviridae, Myoviridae and Podoviridae, respectively as was proposed by Murphy et al. ${ }^{(37)}$ APS3 belonged to family Podoviridae. Frank and Moebus $^{(38)}$ isolated a number of phages belonging to Podoviridae. DePaola et al. ${ }^{(21)}$ also reported the existence of phages belonging to Podoviridae in bivalves.

Random amplification of polymorphic DNA (RAPD) technique is used extensively for the epidemiological investigation and differentiation of many microorganisms. ${ }^{(39-}$ 42). In the present study, RAPD technique detected some polymorphic regions and differences between the three isolates and confirmed that they were not identical.

In the present study, SDS PAGE analysis of APS3 showed three major bands with molecular masses of 46,30 and $17 \mathrm{KDa}$. This range nearly agreed with that of Elshayeb et al., ${ }^{(43)}$ who found that SDSPAGE analysis of purified phages showed three major bands with apparent molecular masses of 47,34 and $16 \mathrm{kDa}$. It was also consistent with the results reported by Barbian and Minnick. ${ }^{(44)}$ There were common bands among the three 
purified phages in the range of $30-46 \mathrm{KDa}$ which was in agreement with Zimmer et al., ${ }^{(45)}$ who found the major capsid component results in size from 47.7 to 34.3 $\mathrm{KDa}$ resembled $43.3 \%$ of total phage protein and the tail protein corresponded to $12.7 \%$ with an apparent size of $27 \mathrm{kDa}$. VPS1 had greater molecular masses than this range. Sen and Ghosh ${ }^{(46)}$ stated the same for vibriophage N5.

The current study showed that VPS1 and APS2 exhibited narrow range of host specificity, which can be explained by the fact that most of the marine phages are specific and lyse only the original host bacterium as was described. ${ }^{(34,47)}$ On the contrary, APS3 showed wide range of specificity and was able to lyse about $85 \%$ of the host bacteria which was in accordance with Moebus, ${ }^{(48)}$ who suggested that the isolation of phages was easier using hosts that existed in the same environment containing the natural phage population.
In the current work, APS3 was entrapped into calcium alginate beads and its efficiency in controlling the growth rate of A. hydrophila was studied. The entrapped phage particles were better in its effect than the free phage (significant at $p<0.05)$ which was in agreement with that reported by Fattouh et al. ${ }^{(16)}$ This could be attributed to the hydrophobicity of calcium alginate beads entrapping the phage, retaining the integrity of the beads and preventing their degradation over the course of experiment and thus allowing more surface of contact between the phage and its host as was explained by Kim et al. ${ }^{(26)}$

In the present study, the efficiency of the entrapped phage particles in reducing the growth rate of $A$. hydrophila was better than the free phage only at the first cycle and decreased upon reuse. The same was reported by Flood and Ashbolt, ${ }^{(49)}$ which was inconsistent with that reported by Fattouh et al., ${ }^{(16)}$ who recorded the phage activity for six successive cycles. 


\section{CONCLUSIONS}

Bacteriophages are potential candidates as therapeutic agents. APS3 showed wide range of host specificity to the associated bacteria in the tested sea food samples and could be promising antibacterial agents against the pathogenic bacteria.

\section{RECOMMENDATION}

Further investigations should be undertaken for studying the possible applications of the isolated bacteriophages in aquaculture systems.

\section{REFERENCES}

1. Brier JW. Emerging problem in seafood. Food Cont. 1992; 3: 2-7.

2. Pilet MF, Leroi F. Applications of protective cultures, bacteriocins and bacteriophages in fresh seafood and seafood products. Food Sci Technol. $2011 ; 201$.

3. Taylor SL. Marine toxins of microbial origin. Food Technol. 1988; 42: 94-8.

4. Boutaib R, Marhraoui M, Abdellah MK, Bouchrif B. Comparative study on faecal contamination and occurrence of Salmonella spp. and Vibrio parahaemolyticus in two species of shellfish in Morocco. Open Environ Sci. 2011; 5: 30-7.

5. Sumner J, Ross T. A semi-quantitative seafood safety risk assessment. Int $\mathrm{J}$ Food Microbiol. 2002; 77: 55-9.

6. Stroeher UH, Jedani KE, Manning PA. Genetic organization of the regions associated with surface polysaccharide synthesis in Vibrio anguillarum $\mathrm{O} 1$ and O2: a review. Gene. 1998; 223: 269-82.

7. Janda MJ, Abbot SL. The genus Aeromonas: Taxonomy, pathogenicity and infection. Clin Microbiol. 2010; 23 (1): 35-73.

8. Pasharawipas $\mathrm{T}$, Manopvisetcharean J, Flegel TW. Phage treatment of Vibrio harveyi: A general concept of protection against bacterial infection. Res $J$ Microbiol. 2011; 6: 560-7.

9. Abedon ST. Phages, ecology, evolution. In: Abedon ST, editor. Bacteriophage Ecology. Population growth, evolution, and impact of bacterial viruses. Cambridge: Cambridge University Press; 2008. p. 1-28.

10. Pereira C, Silva YJ, Santos AL, Cunha A, Gomes N, Almeida A. Bacteriophages with potential for inactivation of fish pathogenic bacteria: Survival, host specificity and effect on bacterial community structure. Mar Drug. 2011; 9: 2236-55.

11. Garcia $P$, Martinez $B$, Obeso JM, Rodriguez A. Bacteriophages and their application in food safety. Lett Appl Microbiol. 2008; 47: 479-85.

12. Guenther S, Huwyler D, Richard S, Loessner MJ. Virulent bacteriophage for efficient biocontrol of Listeria monocytogenes in ready-to-eat foods. Appl Environ Microbiol. 2009; 75: 93100.

13. Verpraet $R$, Chair $M$, Leger $P H$, Nelis $H$, Sorgeloos $\mathrm{P}$, De Leenheer A. Live-food mediated drug delivery as a tool for disease treatment in larvi culture. The enrichment of therapeutics in rotifers and Artemia nauplii. Aqua Engin. 1992; 11: 133-9.

14. Lakkis JM, editor. Encapsulation and controlled release technology in food Systems. Oxford: Blackwell Publishing Ltd; 2007.

15. Le-Tien $C$, Millette M, Lacroix M, 
Mateescu MA. Modified alginate matrices for the immobilization of bioactive agents. Biotechnol Appl Biochem. 2004; 39: 189-98.

16. Fattouh FA, El Assar SA, Farag AEM, Hassan SW. Effect of coliphage entrapment on its interaction with the host bacterium. Biotechnol. 2003; 2(2): 94-100.

17. Gervais L, Gela M, Allain BB, Tolba M, Brovko L, Zourob $M$, et al. Immobilization of biotinylated bacteriophages on biosensor surfaces. Sensors and Actuators B. 2007; 125 (2): 615-21.

18. Cademartiri $\mathrm{R}$, Anany $\mathrm{H}$, Gross I, Bhayani R, Griffiths M, Book MA. Immobilization of bacteriophages on modified silica particles. Biomat. 2010; 31(7): 1904-10.

19. Tolab M, Minikh O, Brovko LY, Evoy S, Griffiths W. Oriented immobilization of bacteriophages for biosensor applications. Appl Environ Microbiol. 2010; 76 (2): 528-35.

20. American Public Health Association (APHA). Recommended procedures for the examination of seawater and shellfish. $4^{\text {th }}$ ed. Washington, DC: APHA; 1970.

21. DePaola A, McLeroy S, McManus G. Distribution of Vibrio vulnificus phage in oyster tissues and other estuarine habitats. Appl Environ Microbiol. 1997; 63: 2464-7.

22. Adams MH. Bacteriophages. New York: Interscience Publishers Inc.,; 1959.

23. Sambrook J, Russell DW. Molecular cloning. A laboratory Manual. $3^{\text {rd }}$ ed. New York: Cold Spring Harbor Laboratory Press; 1989.

24. Laemmli UK. Cleavage of the structural proteins during the assembly of the head of the bacteriophage T4. Nature.1970; 227: $680-85$.

25. Ye W, Leung MF, Xin J, Kwong TL, Lee DKL, Li P. Novel core-shell particles with poly (n-butyl acrylate) cores and chitosan shells as an antibacterial coating for textiles. Polymer. 2005; 46: 10538-43.

26. Kim YS, Kim HW, Lee, SH, Shin, KS, Hur HW, Rhee YH. Preparation of alginate-quaternary ammonium complex beads and evaluation of their antimicrobial activity. Internat $\mathrm{J}$ Biolog. Macromolecule. 2007; 41: 36-41.

27. Sokal, RR, Michenu CD. A statistical method for evaluating systematic relationships. University of Kansas Sci Bull. 1958; 38: 1409-38.

28. Sneath $\mathrm{PH}$, Sokal RR. Numerical taxonomy. The principles and practice of numerical classification. San Francisco: W.H. Freeman; 1973.

29. Sneath $\mathrm{PH}$, . Numerical taxcnomy. In: Boone DR, Castenholz RW, editors. Bergey's manual of systematic bacteriology. vol 1. Williams and Wilkins: London; 1973. p. 39-42.

30. Wilkinson L, Hill MA, Miceli S, Birkenbeuel G, Vang E. Systat for Windows, version 5. Edition. Evanston, 1l; Systay, Inc., Illinois. 1992.

31. Gugliandolo C, Lentinil V, Fera MT, La Camera E, Maugeri TL. Water quality ecological status of the Alcantara River estuary (Italy). New Microbiol. 2009; 32: 77-87.

32. Wright AC, Hill RT, Johnson JA, Roghman MC, Colwellr R, Morris JG. Distribution of Vibrio vulnificus in the Chesapeake Bay. Appl Environ Microbiol. 1996; 62 (18): 717-24.

33. Sousa OV, Vieira RH, DeMenezes FG, DosReis CM, Hofer E. Detection of Vibrio parahaemolyticus and Vibrio cholerae in oyster, Crassostrea rhizophorae, collected from a natural nursery in the Coco river estuary, Ortaleza, Ceara, Brazil. Revista do Instituto de Medicina Tropical São Paulo. 2004; 46: 59-62.

34. Wichels A, Biel SS, Gelderblom HR, Brinkhoff T, Muyzer G, Scht G. 
Bacteriophage diversity in the north Sea. Appl Environ Microbiol.1998; 64: 412833.

35. Adebayo-Tayo BC, Okonko IO, John MO, Odu NN, Nwanze JC, Ezediokpu MN. Occurrence of potentially pathogenic Vibrio species in sea foods obtained from Oron Creek. Adv Biolog Res. 2011; 5: 356-65.

36. Ackerman HW. The first phage electron micrographs. Bacteriophages. 2011; 1 (4): 225-7.

37. Murphy FA, Fauquet, CM, Bishop DH, Ghabrial SA, Jarvis AW, Martelli GP, et al. Virus taxonomy. Classification and nomenclature of viruses: sixth report of the International Committee on Taxonomy of Viruses. New York: Spring Verlag/Wien; 1995.

38. Frank H, Moebus K. An electron microscopic study of bacteriophages from marine waters. Helgol Meeresunters. 1987; 41: 385-414.

39. Jothikumar $\mathrm{N}$, Cliver $\mathrm{O}$, Mariam D, Tadesse W. Immunomagnetic capture PCR for rapid concentration and detection of hepatitis A virus from environmental samples. Appl Environ Microbiol. 1998; 64: 504-8.

40. Priscilla ED, Johnson S, Zimmerley T, Sadowsky MJ. Use of repetitive DNA sequences and the PCR to differentiate Escherichia coli isolates from human and animal sources. Appl Environ Microbiol. 2000; 66: 2572-7.

41. Schaper M, Jofre J. Comparison of methods for detecting genotype of Fspecific RNA bacteriophages and fingerprinting the origin of faecal pollution in water samples. J Virol Methods. 2000; 89: 1-10.
42. Walter J, Tannock GW, TilsalaTimisjarvi A, Rodtong S, Loach DM, Munro K, et al. Detection and identification of gastro-intestinal Lactobacillus species using denaturating gadient gel electrophoresis and speciesspecific PCR primers. Appl Environ Microbiol. 2000; 66: 297-303.

43. Elshayeb AA, Yagoub SO, Yousif AS, Abedalkareem EA, El hag SM, et al . Identification of protein profiles of Escherichia coli, Staphylococcus aureus and their corresponding phages. Amerc J Biotechnol Molec Sci. 2011; 1 (2): 3944.

44. Barbian KD, Minnick MF. A bacteriophage-like particle from Bartonella bacilliforms. Amer J Microbiol. 2000; 146: 599 - 609.

45. Zimmer M, Scherer S, Loessner MJ. Genomic analysis of Clostridium perfringens bacteriophage $\$ 3626$, which integrates into guaA and possibly affects sporulation. J Bacteriol. 2002; 184 (16): 4359-68.

46. Sen A, Ghosh AN. Physicochemical characterization of vibriophage N5. Virol J. 2005; 2: 27.

47. BQeshem KY. Native marine bacteriophages. FEMS Microbiol. 1993; 102: $141-59$.

48. Moebus K. Ecology of marine bacteriophages. In: Goyal SM, Gerba C, Bitton G, editors. Phage Ecology. John Wiley: New York; 1987. p. 137-156.

49. Flood JA, Ashbolt NJ. Virus-sized particles can be entrapped and concentrated one hundred fold within wetland biofilms. Adv Environ Re. 2000; 3 (4): 403-11. 